INDEPENDENT JOURNAL OF MANAGEMENT \& PRODUCTION (IJM\&P) http://www.ijmp.jor.br

V. 8 , n. 4, October - December 2017 ISSN: 2236-269X

DOI: 10.14807/ijmp.v8i4.650

\title{
A CASE STUDY OF SIX SIGMA DEFINE-MEASURE-ANALYZE- IMPROVE-CONTROL (DMAIC) METHODOLOGY IN GARMENT \\ SECTOR
}

\author{
Abdur Rahman \\ Shahjalal University of Science and Technology, Bangladesh \\ E-mail: airdipu@gmail.com \\ Salaha Uddin Chowdhury Shaju \\ Shahjalal University of Science and Technology, Bangladesh \\ E-mail: sust007@gmail.com \\ Sharan Kumar Sarkar \\ Shahjalal University of Science and Technology, Bangladesh \\ E-mail: sharan.sarkar303@gmail.com \\ Mohammad Zahed Hashem \\ Shahjalal University of Science and Technology, Bangladesh \\ E-mail: zahedhashem@gmail.com \\ S. M. Kamrul Hasan \\ Shahjalal University of Science and Technology, Bangladesh \\ E-mail: sm.hasankamrul@gmail.com \\ Ranzit Mandal \\ Jahangirnagar University, Bangladesh \\ E-mail: zit966@gmail.com \\ Umainul Islam \\ Snowtex Outwear Ltd, Bangladesh \\ E-mail: umainul77@hotmail.com
}

Submission: $17 / 03 / 2017$

Revision: 27/04/2017 Accept: 08/05/2017

\section{ABSTRACT}

This paper demonstrates the empirical application of Six Sigma and Define-Measure-Analyze-Improve-Control (DMAIC) methodology to reduce product defects within a garment manufacturing organization in Bangladesh which follows the DMAIC methodology to investigate defects, root causes and provide a solution to eliminate these defects. 
INDEPENDENT JOURNAL OF MANAGEMENT \& PRODUCTION (IJM\&P)

http://www.ijmp.jor.br

v. 8, n. 4, October - December 2017

ISSN: 2236-269X

DOI: 10.14807/ijmp.v8i4.650

The analysis from employing Six Sigma and DMAIC indicated that the broken stitch and open seam influenced the number of defective products. Design of experiments (DOE) and the analysis of variance (ANOVA) techniques were combined to statistically determine the correlation of the broken stitch and open seam with defects as well as to define their optimum values needed to eliminate the defects. Thus, a reduction of about 35\% in the garments defect was achieved, which helped the organization studied to reduce its defects and thus improve its Sigma level from 1.7 to 3.4 .

Keywords: Six Sigma; DMAIC; Defects; Garment; Bangladesh

\section{INTRODUCTION}

Six Sigma was proposed first by the Motorola company in the mid-1980s as an approach to improve production, productivity and quality, as well as reducing operational costs (BHOTE; BHOTE, 1991) which has been traditionally used to measure the variation in a process (OMACHONU; ROSS, 2004). In the Six Sigma's terminologies, the Sigma level is denoted as a company's performance (PYZDEK; KELLER, 2010). Particularly, a Six Sigma level refers to 3.4 defects per million opportunities (DPMO) (STAMATIS, 2004).

Brue and Howes (2005) told that Six Sigma is a management philosophy and strategy as well as a problem-solving and improvement methodology that can be applied to every type of process to eliminate the root cause of defects besides being a measure of variability and organization's quality performance. In general, some authors argue that the main benefits that an organization can gain from applying Six Sigma are: cost reduction, cycle time improvements, defect elimination, an increase in customer satisfaction and a significant rise in profits (DALE; WIELE; IWAARDEN, 2007; BREYFOGLE; CUPELLO; MEADOWS, 2001).

Markarian (2004) suggests that not only can the process improvement generated by Six Sigma be used in manufacturing operations, but also it is the case for the project presented in this paper as well as it can also be expanded to improve business sectors such as logistics, purchasing, legal and human resources. Kumar et al. (2008) state that although Six Sigma is normally used in defects reduction (industrial applications), it can also be applied in business processes and to develop new business models. 
Banuelas et al. (2005) claim that other benefits such as an increase in process knowledge, participation of employees in Six Sigma projects and problem solving by using the concept of statistical thinking can also be gained from the application of Six Sigma. To illustrate this point, during the utilization of Six Sigma in this research project, several tools and techniques were employed.

One of the Six Sigma's distinctive approaches to process and quality improvement is DMAIC (GARZA-REYES, et al. 2010). The DMAIC model refers to five interconnected stages i.e. define, measure, analyze, improve and control that systematically help organizations to solve problems and improve their processes. Dale et al. (2007) briefly defines the DMAIC phases as follows:

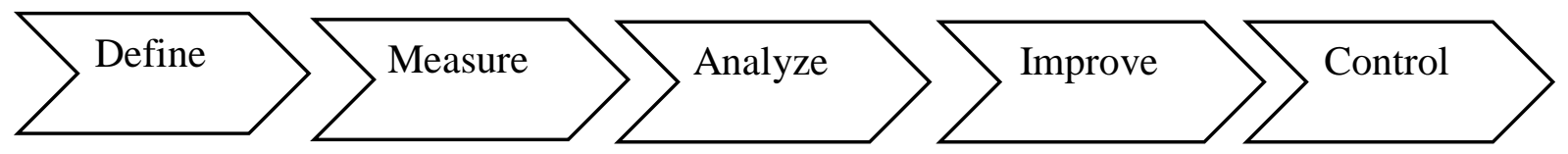

\begin{tabular}{|l|l|l|l|l|}
\hline $\begin{array}{l}\text { What is the } \\
\text { problem? }\end{array}$ & $\begin{array}{l}\text { What data is } \\
\text { available? }\end{array}$ & $\begin{array}{l}\text { What are the root } \\
\text { causes of the } \\
\text { problem? }\end{array}$ & $\begin{array}{l}\text { Do we have the } \\
\text { right solutions? }\end{array}$ & $\begin{array}{l}\text { What do we } \\
\text { recommend? }\end{array}$ \\
\hline $\begin{array}{l}\text { What is the } \\
\text { scope? }\end{array}$ & $\begin{array}{l}\text { Is the data } \\
\text { accurate? }\end{array}$ & $\begin{array}{l}\text { Have the root } \\
\text { causes been } \\
\text { verified? }\end{array}$ & $\begin{array}{l}\text { How will we verify } \\
\text { the solutions } \\
\text { work? }\end{array}$ & $\begin{array}{l}\text { Is there support } \\
\text { for our } \\
\text { suggestion? }\end{array}$ \\
\hline $\begin{array}{l}\text { What key metric is } \\
\text { important? }\end{array}$ & $\begin{array}{l}\text { How should we } \\
\text { stratify the data? }\end{array}$ & $\begin{array}{l}\text { Where should we } \\
\text { focus our efforts? }\end{array}$ & $\begin{array}{l}\text { Have the } \\
\text { solutions been } \\
\text { piloted? }\end{array}$ & $\begin{array}{l}\text { What is our plan } \\
\text { to implement? }\end{array}$ \\
\hline $\begin{array}{l}\text { Who are the } \\
\text { stakeholders? }\end{array}$ & $\begin{array}{l}\text { What graphs } \\
\text { should we make? }\end{array}$ & $\begin{array}{l}\text { What clues have } \\
\text { we uncovered? }\end{array}$ & $\begin{array}{l}\text { Have we reduced } \\
\text { variation? }\end{array}$ & $\begin{array}{l}\text { Are result } \\
\text { sustainable? }\end{array}$ \\
\hline
\end{tabular}

Define - this stage within the DMAIC process involves defining the team's role, project scope and boundary, customer requirements and expectations and the goals of selected projects (GIJO; SCARIA; ANTONY, 2011).

Measure - this stage includes selecting the measurement factors to be improved (OMACHONU; ROSS, 2004) and providing a structure to evaluate current performance as well as assessing, comparing and monitoring subsequent improvements and their capability (STAMATIS, 2004).

Analyze - this stage centers on determining the root cause of problems (defects) (OMACHONU; ROSS, 2004), understanding why defects have taken place as well as comparing and prioritizing opportunities for advance betterment (ADAMS; GUPTA; WILSON JR. 2003). 
INDEPENDENT JOURNAL OF MANAGEMENT \& PRODUCTION (IJM\&P)

http://www.ijmp.jor.br

v. 8 , n. 4, October - December 2017

ISSN: 2236-269X

DOI: 10.14807/ijmp.v8i4.650

Improve - this step focuses on the use of experimentation and statistical techniques to generate possible improvements to reduce the amount of quality problems or defects (OMACHONU; ROSS, 2004).

Control - finally, this last stage within the DMAIC process ensures that the improvements are sustained (OMACHONU; ROSS, 2004) and that ongoing performance is monitored. Process improvements are also documented and institutionalized (STAMATIS, 2004).

DMAIC resembles the Deming's continuous learning and process improvement model plan-do-check-act (PDCA) (DEMING, 1993). Within the Six Sigma's approaches, DMAIC assures the correct and effective execution of the project by providing a structured method for solving business problems (HAMMER; GODING, 2001).

Pyzdek (2003) considers DMAIC as a learning model that although focused on executing improvement activities, emphasizes the collection and analysis of data previously to the execution of any improvement initiative. This provides the DMAIC's users with a platform to take decisions and courses of action based on real and scientific facts rather than on experience and knowledge as it is the case in many organizations, especially small and medium size enterprises (GARZA-REYES, et al. 2010).

Statistically, Six Sigma refers to a process quality measurement and the nearest specification limit is at least six times the standard deviation of the process (FURSULE; BANSOD; FURSULE, 2012). At present, the application of Six Sigma can be found in areas ranging from facility management and maintenance functions (HOLTZ; CAMPBELL, 2004), online market research (RYLANDER; PROVOST, 2006), supply chain improvement (KNOWLES, et al. 2005), such non-manufacturing areas as healthcare management (REVERE; BLACK, 2003), managerial accounting ALBRIGHT; LAM, 2006), and human resources management (WYPER; HARRISON, 2000).

The formulation and identification of useful theories related to Six Sigma development have also been proposed (LINDERMAN, et al. 2003). In the Six-Sigma program, sigma stands for standard deviations from the mean of a data set, in other words a measure of variation among the data set, while Six-Sigma stands for six 
INDEPENDENT JOURNAL OF MANAGEMENT \& PRODUCTION (IJM\&P)

http://www.ijmp.jor.br

v. 8, n. 4, October - December 2017

ISSN: 2236-269X

DOI: 10.14807/ijmp.v8i4.650

standard deviations from the mean. People in industries from manufacturing to service are witnessing the growth of a strategic continuous improvement concept called Six-Sigma (HARRY, 1998).

Six Sigma is a business improvement strategy used to improve profitability, to drive out waste, to reduce costs and improve the effectiveness and efficiency of all operational processes that meet or exceed customer's expectations (ANTONY; BANUELAS, 2001).

Product Design is a process of creating a new product from an organization or business entity for its customer. Being part of a stage in a product life cycle, it is very important that the highest levels of effort are being put in the stage (SHAHRIZAL, 2013).

Pointed out many components of successful Six-Sigma implementation as upper management support, organizational infrastructure, training, tools, link to human resource based actions measurement system and information technology infrastructure (HENDERSON; EVANS, 2000).

Highlighted that continuous improvement techniques are the recognized way of making significant reduction in production costs (HOERL, 2001). Finally, the objective of Six-Sigma is to reduce the variation in the process and defects of the final product (GEOFF, 2001).

\subsection{Background of the study}

First the line defect rate was more than $60 \%$, whereas the project defect rate is $43 \%$ respectively. Because of all buyers wants to check AQL level 2.5 , the target would be project defect rate reduces less than $2 \%$. If we want to pass our good garments for shipment within Buyer required AQL 1.5\% or 2.5\%, we must fix upon an average $2 \%$ defect rate in a line or factory.

\subsection{Methodology}

We have used Six Sigma and Define-Measure-Analyze-Improve-Control (DMAIC) methodology to reduce product defects. Design of experiments (DOE) and the analysis of variance (ANOVA) techniques were combined to statistically determine the correlation between the variable. We have done cause and effects diagram and Pareto analysis. 


\subsection{Case study of Six Sigma and DMAIC application}

DMAIC is a data-driven quality strategy used to improve the defect rate or processes. It is an integral part of a Six Sigma initiative, but in general can be implemented as a standalone quality improvement procedure or as part of other process improvement initiatives such as lean. DMAIC procedure is applied to our project for better tools and techniques used in the driven line for reducing defects rate.

\section{DEFINE}

Revere and Black (2003) suggest that a Six Sigma project should be selected based on company issues related to not achieving customer's expectations. The chosen projects should be focused on having a significant and positive impact on customers as well as obtaining monetary savings. Regarding to these suggestions, the problem selected to be tackled through this project was to reduce quality defects on the product, which clearly comprise both an impact on the customer's expectations and important savings for the organization studied. According to the Linderman et al. (2003) listening to customers is critical for a business to be successful. So, the voice of the customer (VOC) concept, which means identifying what the

Table 1: Summary of the project.

\begin{tabular}{|l|l|}
\hline Project Title: & Defects reduction in garment products \\
\hline $\begin{array}{l}\text { Background and reasons for selecting the } \\
\text { project: }\end{array}$ & $\begin{array}{l}\text { Vast number of garment products has been } \\
\text { rejected by customers due to defective. This } \\
\text { problem causes several types of losses to the } \\
\text { company, i.e. time, materials, capital as well as it } \\
\text { creates customer's dissatisfaction, which } \\
\text { negatively affects the organization's image. }\end{array}$ \\
\hline Project Goal: & $\begin{array}{l}\text { To reduce the defects by 35\% after applying Six } \\
\text { Sigma into the garments manufacturing process. }\end{array}$ \\
\hline Voice of the Customer (VOC): & Product's quality. \\
\hline Team members: & $\begin{array}{l}\text { Production manager, an experienced shop-floor } \\
\text { operator and the improvement project leader. }\end{array}$ \\
\hline Expected Financial Benefits: & $\begin{array}{l}\text { A considerable cost saving due to the defect } \\
\text { reduction. }\end{array}$ \\
\hline Expected Customer Benefits: & Receiving the product with the expected quality. \\
\hline
\end{tabular}

Customers want and serving priorities to their needs (HARRY, 1998), was used in this project to define, based on customer requirements we have select project's objective. From this point, voice of customer also ensured that the project problem, which was defects reduction, became first priority for the improvement team and the organization. 
INDEPENDENT JOURNAL OF MANAGEMENT \& PRODUCTION (IJM\&P)

http://www.ijmp.jor.br

v. 8, n. 4, October - December 2017

ISSN: 2236-269X

DOI: 10.14807/ijmp.v8i4.650

A project summary, which is a tool used to document the targets of the project and other parameters at the outset (LINDERMAN, et al. 2003) which was employed to state and present the project's information structure as well as the summary of the project, VOC, goal and the team's role in this research project. The summary of the project is presented in Table 1.

\section{MEASURE}

The 'measure' phase of the DMAIC problem solving methodology consists of establishing reliable metrics to help monitoring progress towards the goal (PYZDEK, 2003), which in this research consisted of reducing the number of quality defects in the garments manufacturing process. Particularly, in this project the 'measure' phrase meant the definition and selection of effective metrics to clarify the major defects which needed to be reduced (OMACHONU; ROSS, 2004).

We were using two metrics to compare the 'before and after' states of the garments manufacturing process when conducting the Six Sigma's projects. After defining the total number of defects, Sigma level of the garments manufacturing process was calculated. Here we have selected the C-14 line for the pilot run. The project was started from $1^{\text {st }}$ November, 2016.

And its duration was taken 90 days, which ends on $31^{\text {st }}$ January, 2017. The project was TQM base. All party's involvement to reduce the project defect rate less than $2 \%$ is our goal which will impact our quality and efficiency.

Table2: Defects summary before the improvement.

\begin{tabular}{|l|c|c|}
\hline Type of defects & Number of defects & Percentage of defects \\
\hline Broken & 412 & 48.53 \\
\hline Skip & 211 & 24.85 \\
\hline Open & 195 & 22.97 \\
\hline Puckering & 31 & 3.65 \\
\hline Total & 849 & 100 \\
\hline
\end{tabular}

As a next step, a Pareto analysis [36, 37] was carried out to identify the utmost occurring defects and prioritize the most critical problem which was required to be tackled. The collected data was generated in the form of a Pareto chart, which is illustrated in Figure 1. The Pareto chart shown in Figure 1 indicated that the highest rate of defects was caused by breaking stitch which contributed to over 48.52 percent of the overall number of defects. 
Therefore, the improvement team and the organization decided to initially focus on the reduction of the broken stitch defect. The broken stitch defect rate was then translated into the Sigma levels as 1.7 Sigma. The calculation of the Sigma metrics allowed the improvement team and organization to have a more detail and operational definition of the current state of the garments manufacturing process as well as the Six Sigma's goal in terms of the garments process improvement.

These are shown in Table 3. The next stage in the Six Sigma project and following the DMAIC methodology, consisted in analyzing the root causes of this problem as well as identifying an appropriate solution.

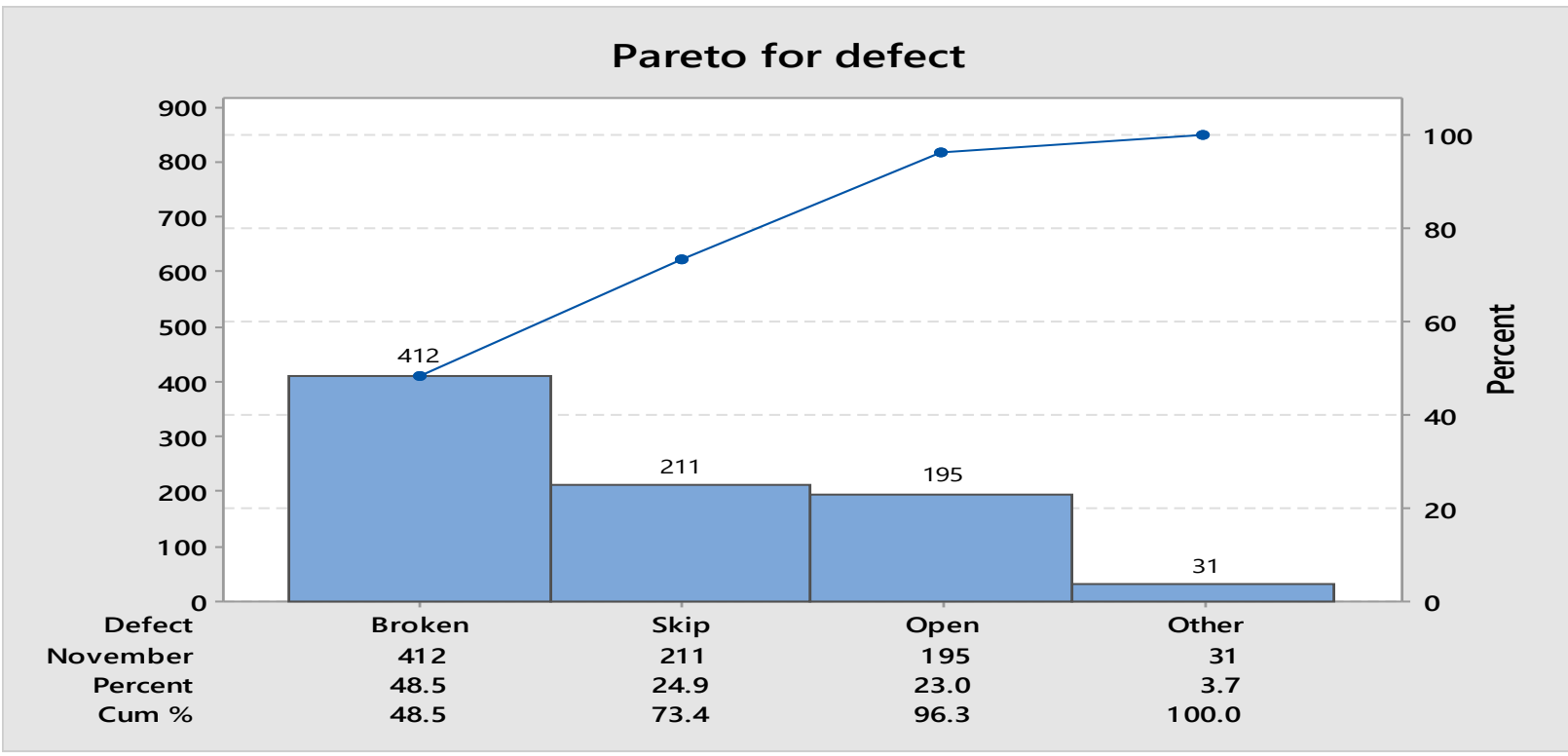

Figure 1: Pareto for project line defect before implementation.

Table3: Manufacturing process - Current and Expected States.

\begin{tabular}{|l|c|c|c|c|}
\hline \multirow{2}{*}{ Major Types of Defects } & \multicolumn{2}{|c|}{ Number of Major Defects } & \multicolumn{2}{|c|}{ Sigma Levels } \\
\cline { 2 - 5 } & $\mathrm{C}^{*}$ & $\mathrm{E}^{*}$ & $\mathrm{C}^{*}$ & $\mathrm{E}^{*}$ \\
\hline Broken & 412 & 174 & 1.7 & 3.4 \\
\hline
\end{tabular}

$\mathrm{C}^{*}=$ Current process performance $\mathrm{E}^{*}=$ Expected process performance after the completion of the sixsigma project

\section{ANALYZE}

This phase in the DMAIC improvement methodology involves the analysis of the system, in this case the manufacturing process that produces the garment product to identify ways to reduce the gap between the current performance and the desired goal (GARZA-REYES, et al. 2010). To do this, an analysis of the data is performed in this phase, followed by an investigation to determine and understand the root cause of the problem (BREYFOGLE III; CUPELLO; MEADOWS, 2001). 


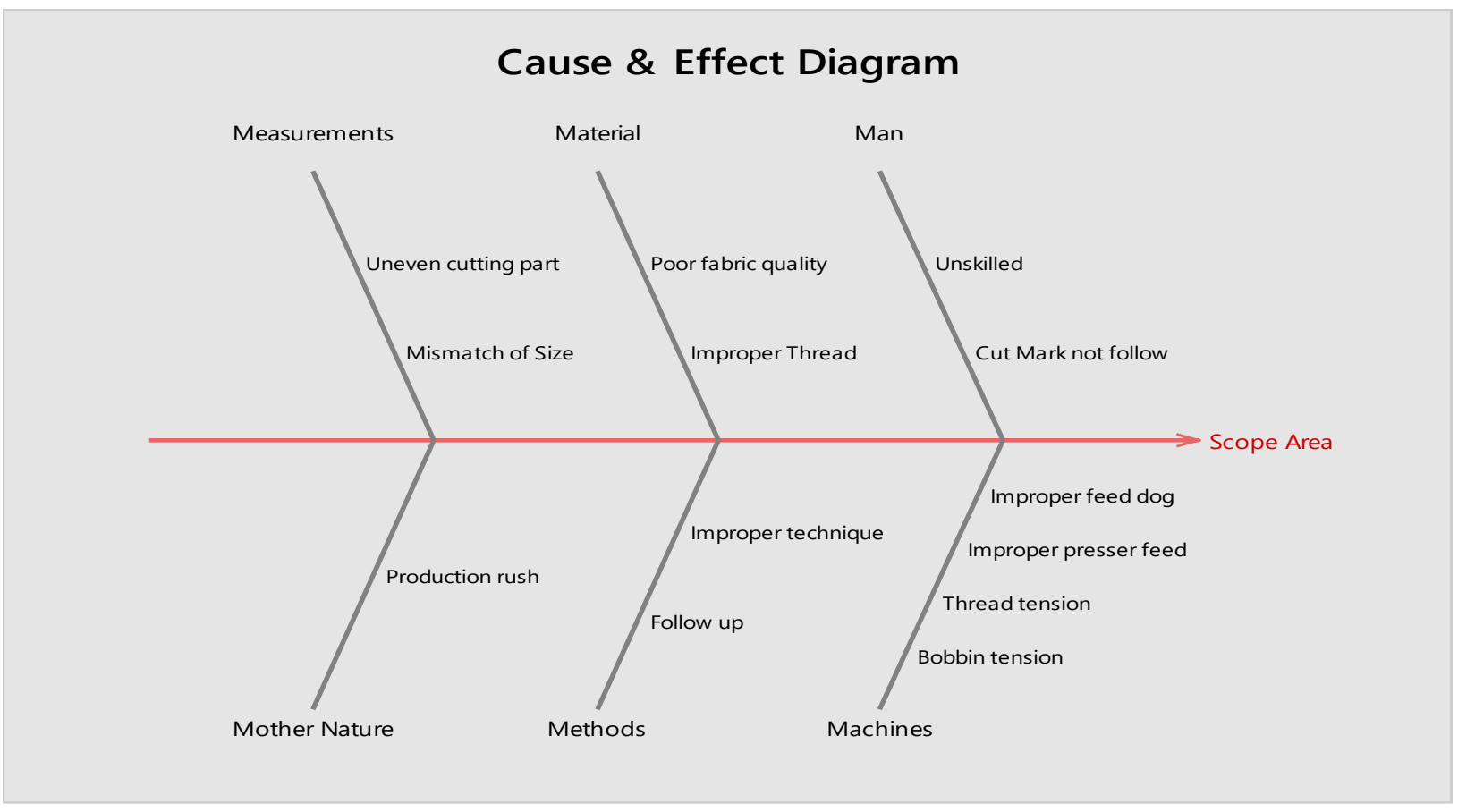

Figure 2: Cause and effect diagram for scope area.

Henderson and Evans (2000) defines that to gain an enhanced comprehension and understanding of the garment production process is a main requirement for improvement. An analysis was carried out to identify the root causes of the broken stitch defect.

Several brainstorming sessions were conducted to identify based on the improvement team member's experience, probable causes as to why the problem in product occurred. To illustrate and categorized the probable causes of the problem, a cause-and-effect diagram (Figure 2) was constructed.

The cause-and-effect diagram, also known as Ishikawa or Fishbone diagram, is known as a systematic questioning technique for seeking the root causes of problems (ANTONY; BANUELAS, 2001) by providing a relationship between an effect and all plausible causes of such effect (OMACHONU; ROSS, 2004). Once completed, the diagram helps to uncover the root causes and provide ideas for further improvement (DALE; WIELE; IWAARDEN, 2007).

There are five main categories normally used in a cause-and-effect diagram which is known as $5 \mathrm{M}$, namely: machinery, manpower, method, material and measurement (DALE; WIELE; IWAARDEN, 2007) plus an additional parameter environment. The possible root causes brainstormed are illustrated in the cause-and- 
INDEPENDENT JOURNAL OF MANAGEMENT \& PRODUCTION (IJM\&P)

http://www.ijmp.jor.br

v. 8, n. 4, October - December 2017

ISSN: 2236-269X

DOI: 10.14807/ijmp.v8i4.650

effect diagram shown in Figure 2. After considering all possibilities, it was found that some stages and operations i.e. improper threading, poor clamping or insufficient pressure (flagging), wrong size needle, wrong type of needle for the material within the garments manufacturing process had an impact on causing the broken stitch.

\section{IMPROVE}

After the root cause(s) has been determined, the DMAIC's improve phase aims at identifying solutions to reduce and tackle them (OMACHONU; ROSS, 2004). Stamatis (STAMATIS, 2004) suggests the use of design of experiments (DOE), which is defined as a statistical technique to investigate effects of multiple factors (KUMAR, et al. 2008; BANUELAS; ANTONY; BRACE, 2005), in the improve phase.

By Garza-Reyes, et al. (2010), benefits of DOE be enhancing process yields, decreasing variability and lowering the overall expenses. The DOE technique was used to investigate whether the assumed correlation was statistically significant or not. An experiment was designed to investigate whether the parameters had a negative effect on the process, causing defect products. To do this and to analysis the experiment's results, the analysis of variance (ANOVA) was used. ANOVA is a statistical model for comparing differences

Table 4: Analysis of Variance (ANOVA).

\begin{tabular}{|l|c|c|c|c|c|}
\hline Source & $\begin{array}{c}\text { Degrees of } \\
\text { Freedom }\end{array}$ & Adj SS & Adj MSS & F-Value & P-Value \\
\hline Defect & 4 & 93.53 & 23.38 & 7.60 & $0.000^{*}$ \\
\hline Parts & 2 & 2.24 & 01.12 & 0.36 & 0.695 \\
\hline Process & 20 & 76.62 & 03.83 & 1.25 & 0.213 \\
\hline Error & 399 & 1227.04 & 3.075 & & 0.913 \\
\hline Lack-of-Fit & 75 & 185.82 & 2.478 & 0.77 & \\
\hline Pure Error & 324 & 1041.21 & 3.214 & & \\
\hline Total & 425 & 1489.03 & & & \\
\hline \multicolumn{7}{l}{ *5\% level of Significance }
\end{tabular}

Among means of more than two populations (GIJO; SCARIA; ANTONY, 2011). However, if there are two sources of data that need to be investigated, ANOVA, which is a statistical methodology for analyzing the effect of the factors, is required (GIJO; SCARIA; ANTONY, 2011). The results of ANOVA analysis are shown in Table 4.

Analysis of Variance tells that the overall variation is accounted by the average response variables. The above analysis shows that the assume hypothesis is statistically significant to be P-value $<0.05$. So, there is a significant effect among 
INDEPENDENT JOURNAL OF MANAGEMENT \& PRODUCTION (IJM\&P)

http://www.ijmp.jor.br

v. 8, n. 4, October - December 2017

ISSN: 2236-269X

DOI: 10.14807/ijmp.v8i4.650

the complete process. Another hypothesis tells the mean difference between the individual treatment mean. Some treatments have a statistically significant mean different effect that means they are highly correlated to occur defect. They are Broken stitch, Open seam, Arm hole and Side pocket.

\section{CONTROL}

The real strength of the DMAIC steps is in the Control step. Whole teams do a lot of arduous work to improve the process and results and then implementation of the improved process don't go smoothly. There is pressure to move on, time is not spent on having a smooth transition and the buy-in for full implementation just is not quite there.

The result is that sustaining the improvement realized in the improve step becomes difficult. The purpose of the control step is to ensure a successful implementation of the team's recommendation so that long-term success will be attained. Then the improved process will be flow charted and these new methods will become the new standard operating procedures.

Results will continue to be tracked so that any drift back to previous results can be monitored and addressed in a proactive manner. The control step is about the transfer of responsibilities and establishing plans for long-term process control.

\section{RESULT}

From the figure 3 we see that initial project Defect Rate (DR) was too high, that is 43 to 39 percent and which was gradually decreasing day after day within one month. Finally, it shows the 7 percent defect rate at the end of one month.

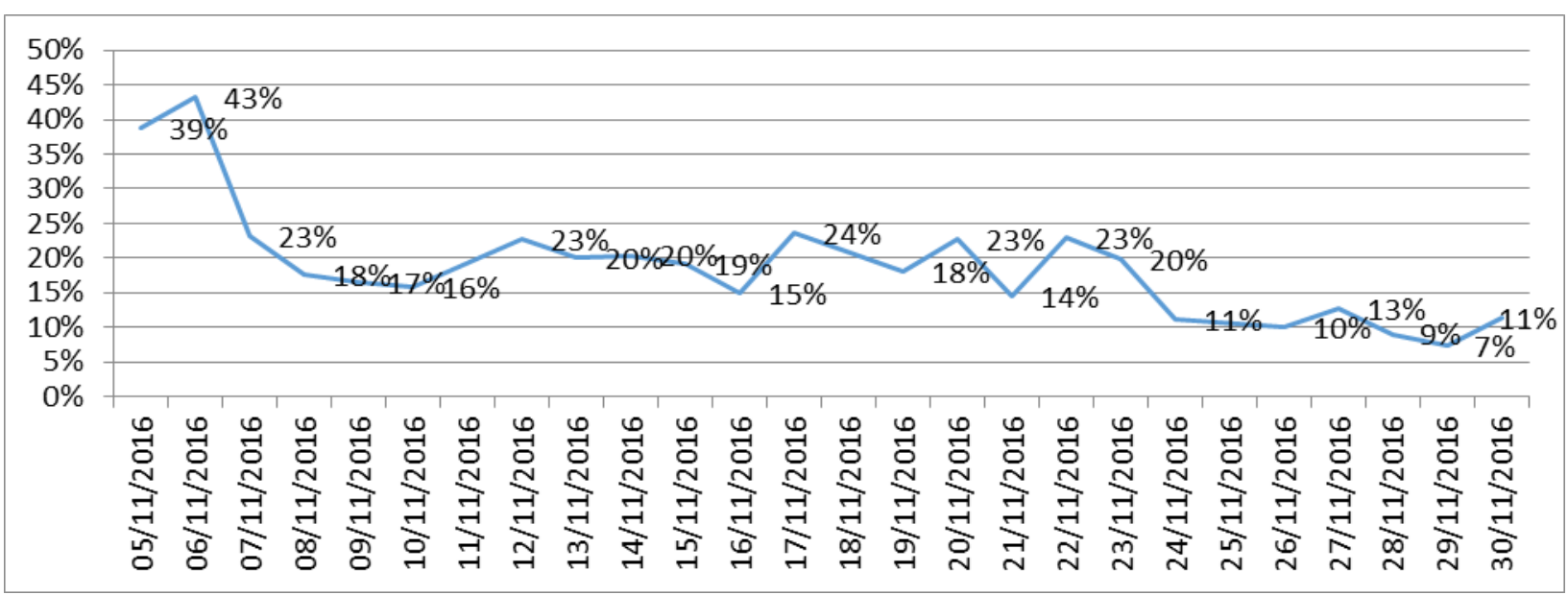

Figure 3: Project defect rate(DR) before implimentation. 
INDEPENDENT JOURNAL OF MANAGEMENT \& PRODUCTION (IJM\&P)

http://www.ijmp.jor.br

v. 8, n. 4, October - December 2017

ISSN: 2236-269X

DOI: 10.14807/ijmp.v8i4.650

We see from the figure 4 that initial project Defect Rate (DR) was too high that, is 17 to 14 percent and which was gradually decreasing day after day within the deadline. Finally, it shows the 2 percent defect rate at the end of the project deadline.

Also from the figure 5 shows that, the initial Sigma level of the project was defined 1.7 and also shows that it is increasing day by day after implementing necessary steps for the defect reduction project. At the end of the project is being seen that we have achieved the 3.4 Sigma which one is good but not best.

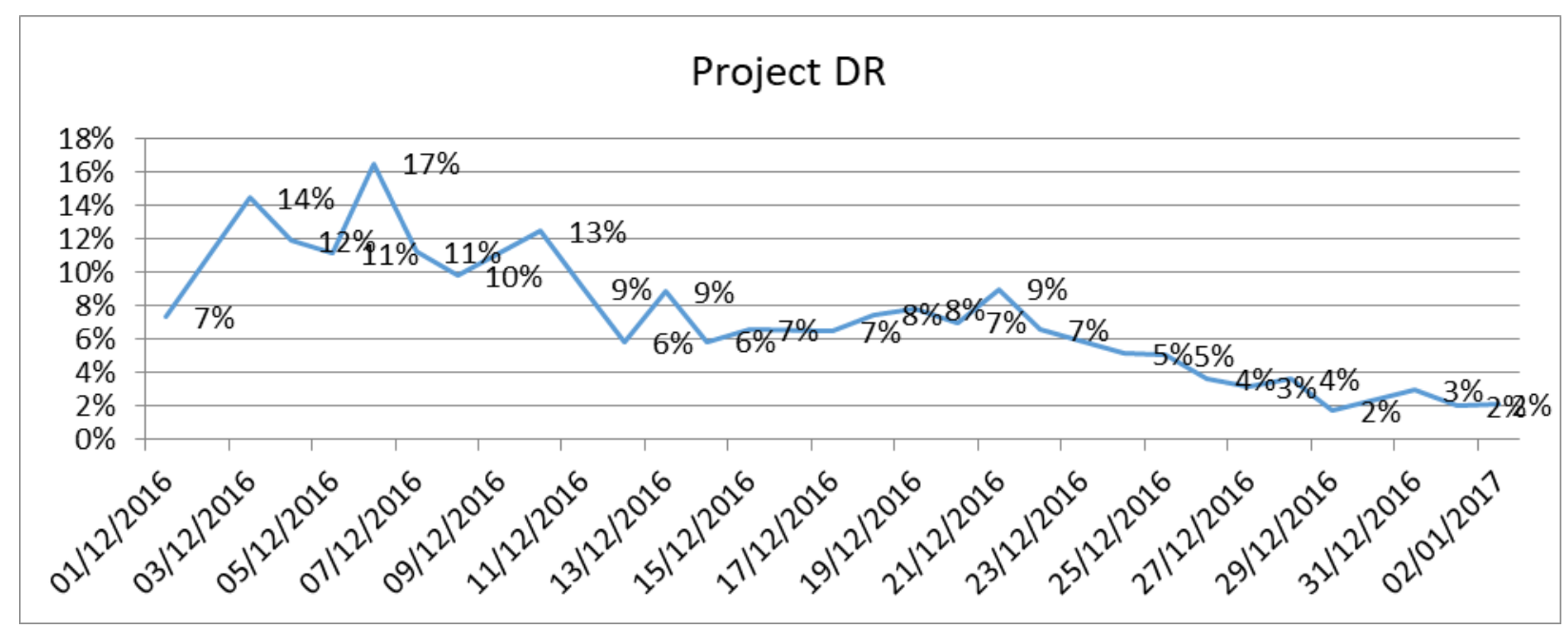

Figure 4: Project defect rate(DR) after impimentation DMAIC.

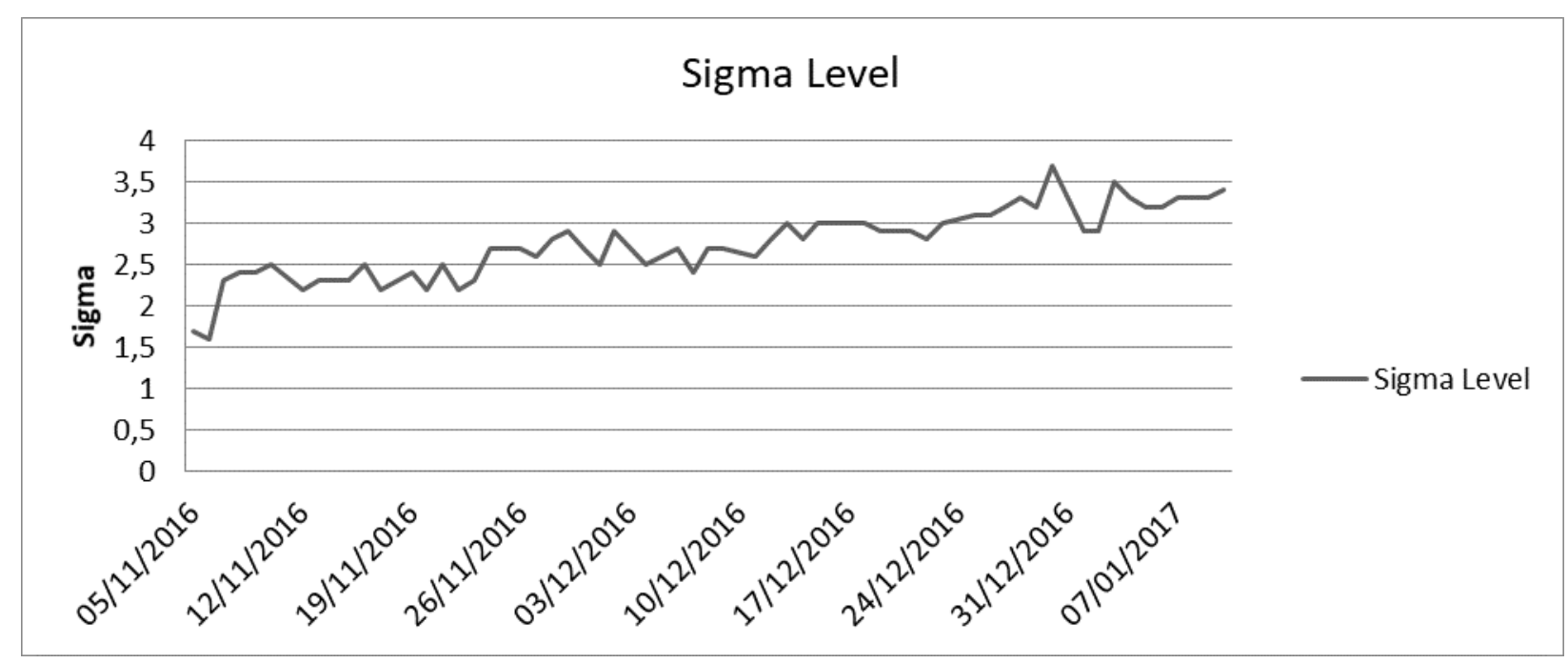

Figure 5: Project Sigma level. 


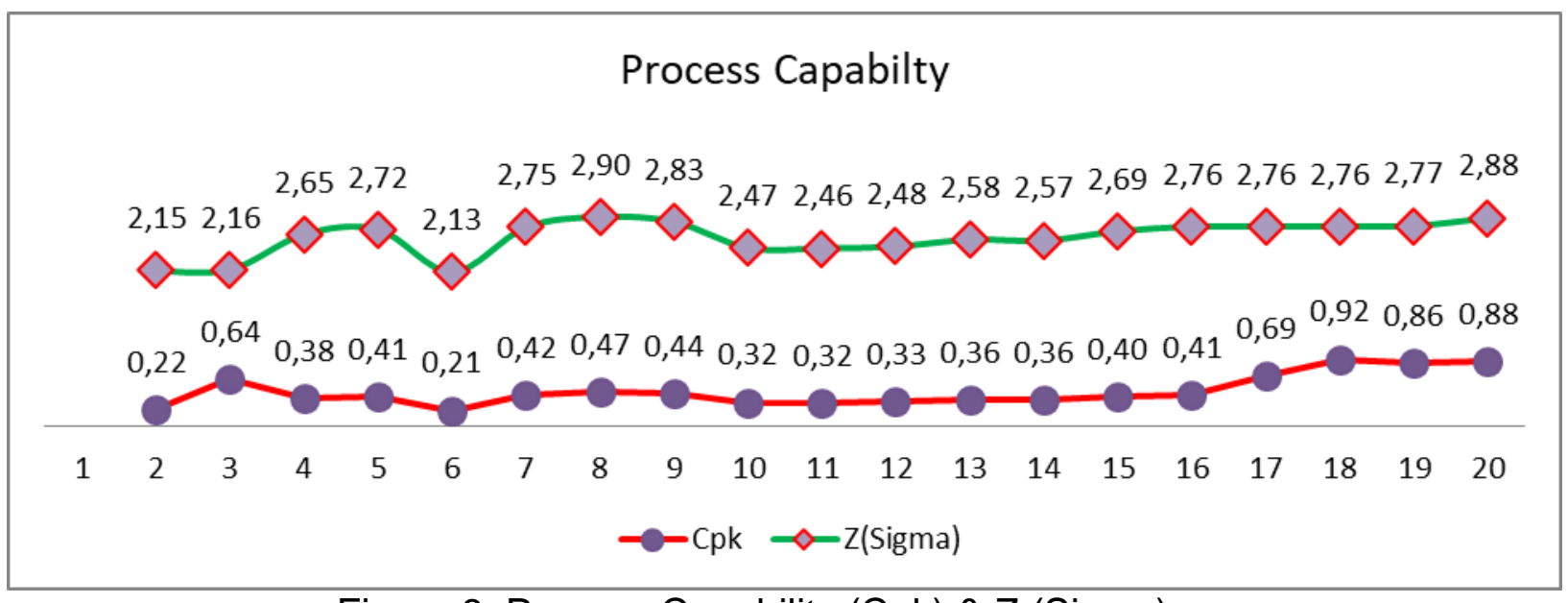

Figure 6: Process Capability (Cpk) \& Z (Sigma).

Also from the figure 6 shows that is the other tool for reducing the process variability and to improve the quality based product which is process capability (Cpk) and Sigma. It tells that the Cpk value is about 0.88 too low, that means process variability is so high besides $Z$ (sigma) is also about 2.88 too low. Every businessman or manufacturers desire 1.33 .

\section{CONCLUSION}

The primary goal of this project is to identify action initiatives that make up the help of conducting the project in the next step to reduce the defect rate at $2 \%$, which is the main objective of the project and to increase the productivity and quality goods.

The Defect Reduction Project report shows that if it has been taken proper steps, then many defects are reduced by only applying some scientific method and shows that process capability (Cpk) is an effective tool to reduce the variability and to increase the productivity and ensure the more quality product.

At the end of our project deadline, we have been able to achieve the desired $2 \%$ defect rate. Finally, we can say that all types of assignable causes are able, to control by reducing defects and continuous improvement process.

Acknowledgment: We want to give thanks to the Managing Director of Snowtex Outerwear Ltd. S M Khalid Hasan for giving the opportunity and inspiration to run the project.

Conflict of Interest: We declare that there is no conflict of interest. 


\section{REFERENCES:}

ADAMS, C. W.; GUPTA, P.; WILSON JR., C. E. (2003) Six Sigma deployment, Elsevier Science, Burlington USA.

ALBRIGHT T.; LAM M. (2006) Managerial Accounting and Continuous Improvement Initiatives: A Retrospective and Framework., Journal of Managerial Issues, v. 18, n. 2, p. 157-174.

ANTONY, J.; BANUELAS, R. (2001) Six Sigma: A Business Strategy for Manufacturing Organization. Manufacturing Engineering, v. 8, n. 3, p. 119-121.

BANUELAS, R.; ANTONY, J.; BRACE, M. (2005) An application of Six Sigma to reduce waste, Quality and Reliability Engineering International, v. 21, n. 6, p. 553-570.

BHOTE, K. R.; BHOTE, A.K. (1991) World-class quality: using design of experiments to make it happen, 2nd Edition, American Management Association, New York.

BREYFOGLE III, F. W.; CUPELLO, J. M.; MEADOWS, B. (2001) Managing Six Sigma, John Wiley \& Sons Inc., New York.

BRUE, G.; HOWES, R. (2005) Six Sigma: the MacGraw-Hill 36 hours course, MacGraw-Hill, New York.

DALE, B. G.; WIELE, T.; IWAARDEN, J. (2007) Managing Quality, 5th Edition, Blackwell Publishing Ltd., Oxford.

DEMING, W. E. (1993) The new economic for industry, government, education, MIT Center for Advanced Engineering Studies, Cambridge, MA.

EVERE, L.; BLACK, K. (2003), Integrating Six Sigma with total Quality Management: A Case Example for Measuring Medication Errors. Journal of Healthcare Management, v. 48, n. 6, p. 377-391.

FURSULE, N. V.; BANSOD, S. V.; FURSULE, S. N. (2012) Understanding the Benefits and limitations of Six Sigma Methodolgy, International Journal of Scientific and Research publications, v. 2, n. 1, p. 1-9.

GARZA-REYES, J. A.; ORAIFIGE, I.; SORIANO-MEIER, H.; HARMANTO D.; ROCHA-LONA, L. (2010) An empirical application of Six Sigma and DMAIC methodology for business process improvement, Proceedings of the 20th International Conference on Flexible Automation and Intelligent Manufacturing (FAIM), July 12-14, California, US, 92-100.

GEOFF, T. (2001) SIX-SIGMA: SPC and TQM in Manufacturing and Services. Gower Publishing, Chapter 1, The development of quality, 1-3.

GIJO, E. V.; SCARIA, J.; ANTONY, J. (2011) Application of Six Sigma methodology to reduce defects of a grinding process, Quality and Reliability Engineering International, [Online] (3 May 2016).

HAMMER, M.; GODING, J. (2001) Putting Six Sigma in perspective, Quality, v. 40, n. 10, p. 58-63. 
HARRY, M. J. (1998), Six-Sigma: A breakthrough strategy for profitability. Quality Progress, v. 31, n. 5, p. 60-64.

HENDERSON, K. M.; EVANS, J. R. (2000). Successful implementation of Six Sigma: benchmarking general electric company. Benchmarking: An International Journal, v. 7, n. 4, p. 260-281.

HOERL, R. W. (2001), Six-Sigma and the future of the quality profession, Quality Progress, v. 31, n. 6, p. 35-42.

HOLTZ, R.; CAMPBELL, P. (2004), Six Sigma: Its implementation in Ford's facility management and maintenance functions. Journal of Facilities Management, v. 2, n. 4 , p. 320-329.

KNOWLES, G.; WHICKER, L.; FEMAT, J.; CANALES, F. (2005) A conceptual model for the application of Six Sigma methodologies to supply chain improvement.

International Journal of Logistics: Research \& Applications, v. 8, n. 1, p. 51-65.

KUMAR, U.D.; NOWICKI, D.; RAMIREZ-MARQUEZ, J. E.; VERMA, D. (2008) On the optimal selection of process alternatives in a Six Sigma implementation, International Journal of Production Economics, v. 111, n. 2, p. 456-467.

LINDERMAN, K.; SCHROEDER, R.; ZAHEER, S.; CHOO, A. (2003) Six Sigma: a goal-theoretic perspective. Journal of Operations Management, v. 21, n. 2, p. 193203.

MARKARIAN, J. (2004) Six Sigma: quality processing through statistical analysis, Plastics. Additives and Compounding, v. 9, n. 4, p. 28-31.

OMACHONU, V. K.; ROSS, J. E. (2004) Principles of total quality, 3rd Edition, CRC Press LLC, Florida.

PYZDEK, T.; KELLER, P. A. (2010) The Six Sigma handbook: a complete guide for greenbelts, black belts, and managers at all levels, 3rd Edition, McGraw-Hill Companies Inc., New York.

PYZDEK, T. (2003) The Six Sigma handbook: a complete guide for green belts, black belts, and managers at all levels, McGraw-Hill Companies Inc., New York, NY.

RYLANDER, D.; PROVOST, T. (2006) Improving the Odds: Combining Six Sigma and Online Market Research for Better Customer Service. SAM Advanced

Management Journal, v. 71, n. 1, p. 13-19.

SHAHRIZAL, B. M. R. (2013) The Use of Design for Six Sigma (DFSS) Methodology in Product Design. Proceedings of the World Congress on Engineering, v. I, July 3 - 5, London, U.K.

STAMATIS, D. H. (2004) Six Sigma fundamentals: a complete guide to the system, methods and tools, Productivity Press, New York.

WYPER, B.; HARRISON, A. (2000) Deployment of Six Sigma methodology in Human Resource function: a case study. Total Quality Management, July, v. 11, n. 4, p. $720-727$. 